\title{
THE FUNCTIONS OF IDIOMS IN A SENTENCE
}

Tatiana PODOLIUC

The Free International University of Moldova

This article is devoted to the functions of idioms in a sentence. In the work the word idiom is used to define phraseological units. Idioms or phraseological units are properly studied from the point of view of their semantic and structural peculiarities, but their functions in a sentence are not given due attention to. Different transformations can take place in idioms. Very often they are the result of the application of specific transformations in the interests of a witty economy of expression. In other words, the application of the transformation is linked with the achievement of a specific stylistic effect. An idiom can become an institutionalised expression when it is approved by the usage of the language. The usage of an idiom or of a word-group in the sentence creates big problem from linguistic point of view and still there is no unanimity of ideas regarding this point.The origin of an idiom can help the translator to know why and where this or that idiom appeared. It may help to find a right idiomatic set-expression in the target language. The knowledge of the functions of idioms in a sentence can help learners to analyze and translate sentences better. An idiom in the text is investigated as a single lexical unit notwithstanding its structure. The author considers that an idiom can be a subject, a predicative, an object, attribute and adverbial modifier in a sentence.

Key words: idiom, phraseological unit, sentence, semantic, structural, peculiarity.

The aim of this article is to show how phraseological units or idioms function in a sentence. People use idiomatic expressions in their speech during all their life and sometimes even don't realise this. Idioms, or conventionalized multiword expressions, often but not always non-literal, are hardly marginal in English, though they have been relatively neglected in lexical studies of the language. This neglect is especially evident in respect of the investigations connected with the functions of idioms in a sentence. (English Idioms and the Application in Daily Life.www.doc88.com>)

An idiom is a fixed group of words with a special different meaning from the means of the separate words.The traditional and oldest principle for classifying phraseological units is based on their original content and might be called the thematic. L. P. Smith gives in his classification groups of idioms used by sailors, fishermen, soldiers, hunters and associated with the realia, phenomena and conditions of their occupations. This principle of classification is sometimes called etymological.( Smith, Logan. Words and Idioms.www.amazon.ca/...)

The considerable contribution made by Russian scholars in phraseological research cannot be exaggerated. V.Vinogradov's classification system is founded on the degree of semantic cohesion between the components of a phraseological unit. (Виноградов Виктор. Лексикология и лексикография. Избранные труды. Москва: Просвещение, 1977).

The classification system of phraseological units suggested by Professor A. V. Kunin is the latest outstanding achievement in the Russian theory of phraseology. The classification is based on the combined structural-semantic principle as well as 
on the principle of stability.(Kunin, Alexander. English Phraseology. Moscow: Nauka, 1970)

The latest findings show that idiomaticity is the outcome of the interaction of a form, a sense and a situational context. Different transformations can take place in idioms. Very often they are the result of the application of specific transformations in the interests of a witty economy of expression. In other words, the application of the transformation is linked with the achievement of a specific stylistic effect. An idiom can become an institutionalised expression when it is approved by the usage of the language. Idioms brake the normal rules. They do this in two main areas- semantically, with regard to their meaning, and syntactically, with regard to their grammar. As idioms present an indivisible entity they can function in a sentence as any linguistic unit. According to our investigation they can function in a sentence as a subject, a predicate, a predicative, an object, an attribute and an adverbial modifier.

\section{Idioms as a subject}

The thin blue line was standing against crime of teenagers in the suburbs of Paris (The Financial Time.www.financialtime.com/...). - Скудные силы полиции противостояли преступным действиям подростков на окраинах Парижа. The idiomatic expression The thin blue line is used in the function of a subject. The pure idiom is blue line. It consists of the colour adjective and a noun - blue line. But the idiom "the blue line" as it is given in the newspaper is not included in the Longman Dictionary of Idioms. It is a transformed variant of the following idiom "boys in blue". This idiom from the Longman Dictionary is usually used for humorous effect and means "men of the police force or the navy", referring to the blue uniform. (Longman Dictionary of English Idioms. London: Harlow, 1979). In the Penguin Dictionary of English Idioms the idiom is given in three variants: "men/boys in blue" and "the thin blue line against crime".(The Penguin Dictionary of English Idioms. London: Routledge, 1991).

So we see that in the latest edition of dictionaries on idioms the more modern variant is introduced into the language vocabulary. In our example we have this idiom but without its humorous meaning. We understand the thin blue line as the image of a line of policemen standing together, shoulder to shoulder, to fight crime. The only possible transformations or changes in the usage of this idiom are restricted and can be made only in the usage of the verb connecting the first part of the idiom with its second part. We may use stand as in the example from the newspaper, or fight as it is given in the dictionary, or can use our own variant - struggle, etc. The first part of the idiom can be as in all pure idioms be substituted by one word - "policemen", its variance is proved in the possibility to use any connecting verb, and the second part of the idioms can also be transformed: if we use, for example, the verb "to oppose" we do not have to use the preposition "against". The short conclusion on the usage of this idiom is the following. The idiom the thin blue line has become more conventionalized in its usage and that is why it possesses today the additional continuation of meaning against crime that is introduced into the language vocabulary. The idiom functions as one unit, one word, as it can be replaced by one wordsynonym, and as such can be used in any function in which nouns are 
used. In our example we have the idiom in the function of the subject of the sentence with the verb agreeing with the singular form of the noun in the idiom - 'line'.

In the following example we have several idioms used in the succession of the sentences. -I think you remember how we lost this country several years ago. Our experienced career diplomat in the capital screwed up, and we were out in the cold. The pin-striped boys worry me. (Stars and Stripes.www.stripes.com/...) In this example we have a group of sentences united by one topic. In the second and the third sentences the subjects are expressed by idioms. So, we have the expressions our experienced career diplomat and the pin-striped boys. In the first sentence career diplomat is a special word collocation that means diplomats specially trained at the educational institutions for this career. But the collocation is used with humor and it can be said even with sarcastic meaning, because we understand that in reality the career diplomats failed to do what they had to and could not show their skillfulness in the establishing of the political relations between countries of different political systems; so this word collocation is used literally and becomes an idiom. Moreover, it is used in the combination with the phrasal verb screw up which is parallel to the idiom to have one's head screwed on with the substitution of the particle after the verb and with the changing of the meaning of the phrasal verb.

But in this text we think the meaning should be $=$ to cause to become confused, anxious, unhappy, etc. So, we can understand the first part of the sentence from the example: Our experienced career diplomat in the capital screwed up as their fail in the capital of the country to establish friendly relation with the new regime. The Russian translation of the phrasal verb to screw up suitable for the text is исnортить, изгадить, напортачить (Kunin, Alexander. English-Russian Dictionary of Idioms. Moscow : Nauka, 1990). The second part of the whole sentence is and we were out in the cold. Here we have the idiom in the function of the predicative after the link-verb 'to be'. The idiom "out in the cold" is used not in formal style and means not taking part; not included; it is often used after the verbs 'to leave', 'to keep', 'to stay'; in the example we see the usage of the idiom after the verb 'to be'. This sentence can be translated as Hauu 'дипломированные' дипломаты опростоволосились и нас выбросили в никуда. In the second sentence of the example we have a very nice, and idiomatic, synonym to the subject of the first sentence The pin-striped boys. The synonym resembles the idioms with the usage of the words "boys": 'blue-eyed boy', 'golden boy', 'backroom boys', 'the big boys', etc. Even the structure resemblance the abovementioned idioms - a compound adjective (pin-striped) plus noun (boys). The plural form of 'boys' here is necessary because we speak about not one but about many diplomats. So the idiom will be "the pin-striped boy". And it functions as one unit, as the subject of the sentence. In the Longman Dictionary we shall find the meaning of the 'pin-striped'. So: 'pin-stripe' - noun - any of a number of thin usually white lines repeated at regular spaces along usually dark cloth to form a pattern; pin-striped - adjective. The next entry: 'pin-stripes', also 'pinstripe suit', a noun, means a suit made of cloth that has a pattern of pinstripes. 
Thus, we see the figurative meaning in this idiom: the career diplomats who were too liberal and who failed to fulfill their diplomatic mission just because of the clichés in their behaviour. - - Наши 'дипломированные' дипломаты опростоволосились и нас выбросили в никуда. Эти 'специалисть' в костюмах в светлую полосочку доставляют мне беспокойство.

\section{Idioms as a Predicate}

The president had cracked down hard on all the pro-counterrevolution elements and reestablished a hard-line position. Even the former president was not that bad. (Stars and Stripes.www.stripes.com/...)

- Президент жестко сломил сопротивление (предпринял жесткие меры против) всех про-контрреволюционных элементов и установил твердую позицию. Даже предыдущий президент был не настолько плох. The idiom consists of the verb, particle, adverb and a preposition. The main element in the idiom is the verb and that is why the idiom in the form of the verb (with all the following elements) is used as a single element, unit, in the function of the predicate of the sentence in the form of the Past Perfect Tense, Active voice. In the Longman Dictionary of Contemporary English we find "to crack down (on)" means "to take strong and severe action to deal with something bad"( Longman Dictionary of English Idioms. London: Harlow, 1979). Moreover, we can find either a compound noun formed from the idiom: "crack-down" - 'action taken to stop or discourage a bad activity'. The author probably uses this idiom because the general meaning of the main verb of the idiom is 'to break without dividing into separate parts, without splitting', and 'to discover the secret of something'. The idiom at one and the same time possesses all these meanings.

It was the vice-president who had recruited Williams out of college, and Williams had turned out to be one of the best. But in the last few years Williams had become a cowboy - a little too independent, a little too quick on the trigger.( Stars and Stripes.www.stripes.com/...) - Именно вицепрезидент завербовал Уильяма в колледже, а Уильям оказался одним из лучшим. Но за последние несколько лет Уильям стал безответственным, настоящим ковбоем - слишком независимым, слишком быстрым на решения. There are two idioms in the example. One - "to become a cowboy" - is used in the function of the predicate. In the dictionary we see that "cowboy" is not only a person employed to look after cattle, esp. on horseback in North America, but also someone who is careless and dishonest in business. This is the second meaning that is supposed here. Without the verb the word 'cowboy' is not an idiom. Only in the combination with a verb and together with it in the figurative meaning it becomes an idiom. The second idiom is used in the function of an attribute to the idiom "to become a cowboy" describing the quality of "becoming a cowboy". "Too quick on the trigger" is explained as an American idiom «быстро реагирующий, импульсивный». And there is either one more idiom with the word 'trigger' - "easy on the trigger" that means «вспыльчивый, легко возбудимый». We see here that 'on the trigger' remains as main and an unchangeable element in both idioms retaining the general meaning of the verb to trigger in its conversed noun, only the 
usage of different adjectives gives the different meanings to the idioms to some extent similar to each other.

The young minister won his colours with a brilliant defense of the government's policy.( The Financial Time.www.financialtime.com/...)/Молодой министр проявил себя блестящей защитой политики правительства.

The next example of usage of an idiom functioning as the predicate of the sentence: "to win one's colours". This idiom, according to The Penguin Dictionary of English Idioms, means - "to win recognition for one's achievements.( (The Penguin Dictionary of English Idioms. London: Routledge, 1991) The second element of this idiom is the word colours. This word has several meanings: 1) A special sign, cap, badge, etc.; 2) The official flag of a country, ship, part of the army, etc.; 3) one's true colours means one's real (especially unpleasant) character. (The Penguin Dictionary of English Idioms. London: Routledge, 1991).

The reporter has hit the jackpot! He may go and ask a few questions. (Stars and Stripes.www.stripes.com/... )/Репортер сорвал банк! Он может пойти и задать несколько вопросов.

That is the jackpot question! (Stars and Stripes.www.stripes.com/...)/Это вопрос на миллион!

These two examples are connected by the usage of one word - 'jackpot'. In the first examples the idiom 'to hit the jackpot' is used in the function of the predicate of the sentence. In the second examples 'jackpot' is used in the attributive function for the predicative of the link verb 'to be'. In the Longman Dictionary of Contemporary English is written with a hyphen "jack-pot" and means "the biggest amount of money to be won in a game of cards or in any competition decided by chance. (Longman Dictionary of English Idioms. London: Harlow, 1979).

The idiom 'to hit the jackpot' has the meaning 'to get a huge return on one's money all at once; to make a lucky gamble. The phrase is taken from the card game poker, when one scoops the pool'. From the explanations of the word 'jackpot' and the idiom 'to hit the jackpot' we can understand the main idea that huge money could be gained only by chance in any competition. And in the first example we see from the context that the subject of the sentence got the chance to know some very valuable information as if he 'hit the jackpot'. In Russian we may also use an idiom «схватить бога за бороду», «сорвать банк». But that information brought him much evil, so as the result of the 'jackpot' the subject did not manage 'to hit the jackpot' in reality. In the second sentence 'jackpot' in the attributive function does not mean the chance but the huge amount of money. In Russian we can translate it also with colloquial idiom with the meaning of some money as the figurative price of the question: «Это вопрос на миллион!»

\section{Idioms in the Function of a Predicative}

After the link verb "to be".

Iliescu waited for a reaction and went on: "We are descendants of the ancient Dacians and their conquerors, the Romans. For centuries we have been Europe's doormat. The western tribes wiped their feet on us, but Romania has survived.( Stars and Stripes.www.stripes.com/...) - Илиеску 
подождал реакцию и продолжал: «Мы потомки древних даков и их завоевателей, римлян. Веками мы были половой тряпкой для Европы. Западные племена вытирали ноги об нас, но Румыния выжила. The two sentences are connected with each other by the common context. In the first sentence the idiom is used after the link verb in the function of the predicative, in the second sentence the idiom is used as the predicate in the Past Indefinite Tense. The first idiom is represented by only one word (after the link verb) due to its figurative meaning - 'doormat'. The literally meaning is 'a mat placed in front of or inside a door for cleaning one's shoes on'. Figuratively 'to be a doormat' is 'to endure unfair treatment by others without complaining'. In the sentence the idiom is used as an exaggeration. In the second sentence the idea of being someone's doormat is developing further, showing the action of cleaning the feet, changing the 'doormat' into 'wiping their feet on us'.

The idioms in the function of a predicative can be used not only with the verb to be but with other link verbs as well. As soon as Mr. Putin says candidate $X$ or $Y$ should be president, he becomes a lame duck, because the whole Russian elite will immediately orientate themselves around that person," says Alexei Makarkin of Moscow's Centre for Political Technologies(The Financial Time.www.financialtime.com/...) - Как только мистер Путин объявит, что кандидат Икс или Игрек будет президентом, он станет непереизбранным президентом, потому что вся российская элита немедленно переориентируется на этого нового человека», говорит Алексей Макаркин из Московского центра политических технологий.

\section{Idioms as secondary part of the sentence}

\section{- Idioms as an object}

Many politicians think she is the perfect candidate. But, of course, State is not going to be happy. What will you do in this situation?" "We shall send them a crying towel."( Stars and Stripes.www.stripes.com/...) - Многие политики думают, что она великолепный кандидат. Но, конечно, правительство не будет от этого счастливо. Что вы будете делать в этой ситуации?» «Мы пошлем им полотенчико, слёзки вытирать». The idiom 'a crying towel' is used in the function of the direct object after the transitive verb 'to send' and the indirect object expressed by the objective pronoun 'them'. In the Dictionaries of English idioms there is no such idiom. But there is another idiom with the generally main element 'towel': it is 'to throw in the towel'; and the variants without 'towel': 'to throw in the sponge / one's hand'. The idiom 'to throw in one's towel' means 'to abandon a plan or idea, to give up', 'to lose all hope, esp. in a competition or fight.

\section{Idioms in the Function of an Attribute}

The big state financial institution has among its many tasks the role of defending French blue-chip companies.( The Financial Time.www.financialtime.com/...) - Крупный государственный финансовый институт среди множества своих задач включает роль защитника французских надежных компаний. We marked in this example the word combination 'blue-chip companies'. The problem is that the Penguin Dictionary of English Idioms gives two idioms with the word combination 
'blue chips(s)'. First is 'blue chips'; the second is 'shares in a blue-chip company'. The meaning of the second idiom is the following: "shares considered reliable and safe (usually industrial shares); generally said of something renowned and reliable'. There is one more variant of the idiom 'blue-chip clients'. The elements in the second idiom from the Penguin Dictionary are: 'shares', blue-chip' and 'company'. 'Shares' and 'company' do not give us any difficulty in understanding. We have to analyze the variants of the idiom: 'blue chip', 'blue chips' and 'blue-chip' as they are given in different dictionaries. (The Penguin Dictionary of English Idioms. London: Routledge, 1991) In our context the meaning of the word 'chip' is: 'a flat plastic object used for representing money in certain games. As to the word 'blue' - of course, it refers to the colour of the sky, then to the colour of the paper on which the shares are printed, that we also see in the American expression 'blue sky law' that means 'закон, регулирующий выпуск и продажу акций и ценных бумаг'. We see different usage of the idiom 'blue chip'. It may be used with word 'chip' in the singular and in the plural form; can be hyphenated; can be a noun and an adjective. In our example from the newspaper we have it in the form of compound adjective in the function of an attribute to the word 'company' with which it forms the new idiom that means 'reliable companies'.

\section{Idioms in the Function of an Adverbial Modifier}

The President is trying to keep our relations on an even keel.(The Financial Time.www.financialtime.com/...) - Президент старается сохранять наши отношения ровными. From the first glance it seems that the idiom 'on an even keel' in used in the function of an attribute to the word 'relations'. But it is not so, because when we ask questions in order to determine the function of the idiom in the sentence we can only ask the question 'to keep how'. That means that the idiom characterizes the verb and not the noun, so the idiom 'on an even keel' is used in the function of an adverbial modifier of manner. The idiom is given in the Penguin Dictionary of English Idioms in the combination with the link verb 'to be', and in the example we have it with the verb 'to keep'. (The Penguin Dictionary of English Idioms. London: Routledge, 1991) We see that the verb 'to keep' also does not mean strong activity, it is somehow passive and is also used as a link verb to show the constant situation that is going on to be preserved as it was long before. The idiom itself means 'to be calm and undisturbed'. We can not doubt that the idiom originates from sea terminology; and, of course, it means the still water, without any storms at sea, when a ship sails straightly, without bending into her sides. The idiom is a pure idiom, of restricted variance (that means that we can use it with some other verbs), and non-literal.

The President's son-in-law of this Middle East country specialized in suggesting the tourists the places where they could trade in the black market and buy drugs. (The Financial Time.www.financialtime.com/...)/Зять Президента этой среднеазиатской страны специализировался в том, что он предлагал туристам места, где они могли торговать на черном рынке и покупать наркотики. The idiom 'the black market' is used in this example in the function of an adverbial modifier of place after the 
preposition 'in' showing where the trade could be performed. There are some more idioms with the word black such as the black economy, a blackleg, etc. Here we have the following meaning of the colour idiom 'the black market': 'illegal buying and selling of products that have been rationed by the government. And in the Russian language there is also an idiom with this adjective - на черном рынке with the same meaning of something illegal in the trade or in the economy.

\section{Idiom as a Separate Sentence or Clause}

Reds under the bed. (Stars and Stripes.www.stripes.com/...) - Красные повсюду. The idiom 'Reds under the bed' is very clear in meaning, only it needs some clarity: why 'Reds' why with the capital letter, why 'under the bed'. In the Longman Dictionary of Contemporary English we find 'Red' adjective, of derogative meaning, especially in newspapers, 'supporting leftwing political ideas; socialist or communist'; and - noun, also of derogative meaning 'for Communist'. The word is written with the capital letter in order to distinguish red communists from the colour 'red' and from the original Americans with red skin who also are called 'reds', only their nickname is written with small letter. The idiom is used to show the groundless, exaggerated fears of socialists and communists. The idiom is used to show the maniacal idea that possesses the minds of some people, some authorities, and as a means to threaten the population with nonexistent threat.

\section{Conclusions}

The usage of an idiom or of a word-group in the sentence creates big problem from linguistical point of view and still there is no unanimity of ideas regarding this point.

- As the idiom is considered to be a linguistic unit it can function as any part of a sentence.

- In a sentence an idiom can function as a subject, a predicate, a predicative after the link verbs, an attribute, an object, an adverbial modifier.

- $\quad$ The knowledge of the functions of idioms in a sentence can help learners to analyze and translate sentences better.

\section{Bibliographical references}

Dixon, Richard J. Essential Idioms in English. Prentice Hall, 1994.

Fernando, Chitra. Idioms and Idiomaticity. Oxford : O.U.P., 1996.

Kunin, Alexander. English Phraseology. Moscow: Nauka, 1970.

Виноградов В. В. Лексикология и лексикография. Избранные труды. Москва:

Просвещение, 1977.

Longman Dictionary of English Idioms. London: Harlow, 1979.

Kunin, Alexander. English-Russian Dictionary of Idioms. Moscow : Nauka, 1990.

Penguin Dictionary of English Idioms. London: Routledge, 1991.

English Idioms and the Application in Daily Life.www.doc88.com>

Stars and Stripes.www.stripes.com/...

The Financial Time.www.financialtime.com/... 